\title{
Anisotropy-based inclination correction for the Moenave Formation and Wingate Sandstone: implications for Colorado Plateau rotation
}

\section{Andrea M. McCall and Kenneth P. Kodama*}

Department of Earth and Environmental Sciences, Lehigh University, Bethlehem, PA, USA

\section{Edited by:}

John William Geissman, University of Texas at Dallas, USA

\section{Reviewed by:}

Giovanni Muttoni, Università Degli

Studi di Milano, Italy

Julie Bowles, University of

Wisconsin - Milwaukee, USA

\section{*Correspondence:}

Kenneth P. Kodama, Department of Earth and Environmental Sciences, Lehigh University, 1 West Packer

Ave., Bethlehem, PA, USA

e-mail:kpk0@lehigh.edu
The 201 Ma paleopole for North America (NA) at the Triassic-Jurassic boundary (TJB) is observed in two widely different locations; one paleopole is determined from the Mesozoic rift basins in eastern NA and the other from the Colorado Plateau (CP) in the southwestern United States. A large discrepancy in paleopole positions from these two localities has been attributed to large amounts of clockwise vertical axis rotation of the $\mathrm{CP}\left(>10^{\circ}\right)$ combined with inclination shallowing of the paleomagnetism. The sedimentary inclinations of the eastern North American basins have been corrected for shallowing, but the CP inclinations have not. Simple vertical axis rotation of the CP is not enough to bring the two paleopoles into agreement. This study of the Moenave and Wingate Formations was conducted to correct CP inclinations using their high field isothermal remanent anisotropy. The Moenave Formation and laterally equivalent Wingate Sandstone, which span the TJB, were sampled in southern Utah and northern Arizona. Thermal demagnetization isolated a characteristic remanence carried by hematite from 20 sites. High field (5 T) isothermal remanent anisotropy indicated shallowing of the characteristic remanence with an average flattening factor of $f=0.69$. An inclination-corrected paleopole for the Moenave and Wingate Formations is located at $62.5^{\circ} \mathrm{N} 69.9^{\circ} \mathrm{E}$ $\left(\alpha_{95}=5.5^{\circ}\right)$ and is shifted northward by $2.9^{\circ}$ with respect to the uncorrected paleopole. When the inclination corrected paleopole is rotated counterclockwise $9.7^{\circ}$ about an Euler pole local to the $\mathrm{CP}$, it is statistically indistinguishable from the inclination-corrected paleopole from the eastern North American rift basins. Rotation of the uncorrected paleopole does not bring it into statistical agreement with rift basin paleopole, therefore an inclination shallowing correction is necessary to support rotation of the $\mathrm{CP}$ and bring the Moenave and Wingate paleopoles into agreement with the eastern North American basin paleopole.

Keywords: inclination correction, Moenave Formation, Colorado Plateau rotation, Wingate Sandstone, magnetic anisotropy

\section{INTRODUCTION}

The apparent polar wander path (APWP) for North America (NA) during the early Mesozoic has been observed from two widely different locations; in the sedimentary and volcanic rocks of the rift basins in the northeastern United States, and in strata in the American Southwest, on the Colorado Plateau (CP). The APWPs produced are significantly different, with a westward track of the paleopoles derived from the $\mathrm{CP}$ that requires a large $\left(>10^{\circ}\right)$ amount of $\mathrm{CP}$ rotation to reconcile the differences. The largest difference occurs at a cusp (J1) in the CP APWP, at the Triassic-Jurassic boundary (TJB), $201 \mathrm{Ma}$ (Gordon et al., 1984; Ekstrand and Butler, 1989; Molina-Garza et al., 2003; Kent and Olsen, 2008; Walker and Geissman, 2009). The 201 Ma paleopole from the sedimentary units and the Central Atlantic Magmatic Province (CAMP) volcanics in the Newark and Hartford Basins in eastern NA is $67^{\circ} \mathrm{N}, 93.8^{\circ} \mathrm{E}\left(N=3, \alpha_{95}=3.2^{\circ}\right)$ (Kent and Olsen, 2008). The coeval paleopole from the latest Triassic and earliest Jurassic, including the Moenave Formation and Wingate Sandstone, on the CP is $58.8^{\circ} \mathrm{N}, 60.9^{\circ} \mathrm{E}\left(N=6, \alpha_{95}=3.3^{\circ}\right)$ (Molina-Garza et al., 2003). Large amounts $\left(>10^{\circ}\right)$ of vertical axis clockwise rotation of the $\mathrm{CP}$ about an Euler pole local to the CP (Steiner and Lucas, 2000), combined with inclination shallowing of the paleomagnetism is suggested to be the reason for the difference between the pole paths (Kent and Olsen, 2008), but structural, geologic, and some paleomagnetic data suggest that the rotation is limited to less than $5^{\circ}$ (Hamilton, 1981, 1988; Gordon et al., 1984; Bryan and Gordon, 1986, 1990; Cather, 1999; Molina-Garza et al., 2003). Inclination shallowing corrections have been shown to be important for geologically realistic interpretations of paleomagnetic data by many workers, using two different techniques that yield the same result when compared; the anisotropy technique (Kodama and Davi, 1995; Kodama, 1997; Tan and Kodama, 1998, 2002; Vaughn et al., 2005; Bilardello and Kodama, 2009, 2010) and the E/I 
technique (Tauxe and Kent, 2004; Kent and Tauxe, 2005; Kent and Olsen, 2008; Tauxe et al., 2008). Inclination shallowing has been corrected using the E/I technique (Tauxe and Kent, 2004; Kent and Tauxe, 2005; Kent and Olsen, 2008) for the paleopole from the sedimentary units in the eastern NA rift basins, but has not been corrected for the CP paleopole. When MolinaGarza et al's (2003) paleopole is rotated counter-clockwise $17^{\circ}$ about a CP-local Euler pole to bring the longitude into agreement with the inclination corrected coeval eastern NA pole, there is still a difference in latitude of $\sim 9^{\circ}$. Simple vertical axis rotation alone cannot reconcile the differences between the paleopoles.

Determination of an accurate APW path for NA is necessary for reliable paleogeographic reconstructions and better understanding of North American plate motions. The shape of APW path can indicate whether there were abrupt or gradual changes in North American plate motion. If there is truly a cusp in the North American APW path, it would indicate that there were major changes in plate boundaries of NA over a relatively short period of time, the few million years that span the TJB (Lucas and Tanner, 2007a; Kent and Olsen, 2008). If the cusp observed in CP rocks is instead due to $\mathrm{CP}$ rotation, an inclination shallowing correction of $\mathrm{CP}$ rocks can help better constrain the amount of rotation, important to understanding western NA tectonics and better resolution of the NA APW path. A recent North American APW path that is based on igneous paleopoles and inclination-corrected sedimentary paleopoles (Kent and Irving, 2010) assumes $13^{\circ}$ of clockwise rotation and inclination shallowing in the Morrison Formation, in the construction of the APW path. Direct measurement of the inclination shallowing in $\mathrm{CP}$ rocks would test the accuracy of this assumption.

Here, we present new paleomagnetic results from the Moenave Formation and Wingate Sandstone for the 201 Ma paleopole from northern Arizona and southern Utah on the CP that have been corrected for inclination shallowing. These data allow us to make a better comparison of the two different paleopoles for the TJB for NA and to see if there can be a reconciliation of the latitude difference between the $\mathrm{CP}$ paleopole when unrotated and the coeval corrected eastern NA paleopole.

\section{GEOLOGIC SETTING AND PREVIOUS WORK}

The strata and CAMP volcanics from the Newark, Dan RiverDanville, and Hartford rift basins in eastern NA were thoroughly studied paleomagnetically (Kent et al., 1995; Kent and Olsen, 1997, 1999, 2008; Tauxe and Kent, 2004; Kent and Tauxe, 2005). The rocks in these basins were dated by paleomagnetics and chronostratigraphy and span the TJB (Olsen and Kent, 1996; Olsen et al., 1996; Kent and Olsen, 1999, 2008; Hames et al., 2000), as well as biostratigraphy (Olsen et al., 2002; Lucas and Tanner, 2007b), ranging in age from $\sim 203$ to $\sim 199.5 \mathrm{Ma}$ (Kent and Olsen, 1999, 2008). Kent and Olsen (2008) conclude that these basins did not rotate with respect to each other based on the agreement of their inclination-corrected paleopoles, suggesting that they have not experienced significant vertical axis rotations with respect to cratonic NA. Also, a positive fold test that resulted from comparison of results from the Newark and
Hartford basins (Kent and Olsen, 2008) indicates that the basins have remained coherent. Kent and Olsen (2008) combined inclination shallowing-corrected sedimentary results using the E/I technique (Tauxe and Kent, 2004) in the Newark and Hartford basins with the CAMP volcanic data from these basins, allowing the calculation of a $201 \mathrm{Ma}$ paleopole for NA. Finally, they averaged several workers' paleopoles from the CP at $201 \mathrm{Ma}$, and rotated the uncorrected average paleopole counterclockwise 13.5 ${ }^{\circ}$ about a CP local Euler pole (Hamilton, 1981, 1988; Kent and Witte, 1993). They found that the uncorrected mean CP paleopole does not overlap the coeval eastern NA inclinationcorrected paleopole; a disagreement in latitude of $\sim 7^{\circ}$ remained, which could be reconciled by an inclination correction for the $\mathrm{CP}$ paleopole.

The CP is a coherent tectonic province in the American Southwest that rotated clockwise with respect to cratonic NA during Laramide tectonism and the opening of the Rio Grande Rift system, (Hamilton, 1981, 1988; Gordon et al., 1984; Steiner, 1986, 1988; Bird, 1998; Molina-Garza et al., 1998; Cather, 1999; Wawrzyniec et al., 2002). The amount of rotation has been debated by researchers for nearly 30 years and ranges from 1 to $17^{\circ}$ (Hamilton, 1981, 1988; Kent and Witte, 1993; Cather, 1999; Steiner and Lucas, 2000; Molina-Garza et al., 2003; Kent and Olsen, 2008).

Previous studies have observed paleomagnetic directions consistent with the TJB-age J1 cusp paleopole in the Moenave Formation and the laterally equivalent Wingate Sandstone (Gordon et al., 1984; Ekstrand and Butler, 1989; MolinaGarza et al., 2003; Donohoo-Hurley et al., 2010). The Moenave Formation is a series of red beds comprised of fluvial and lacustrine mudstone and siltstone, as well as eolian sandstone of near equatorial continental origin (Figures 1A,B)

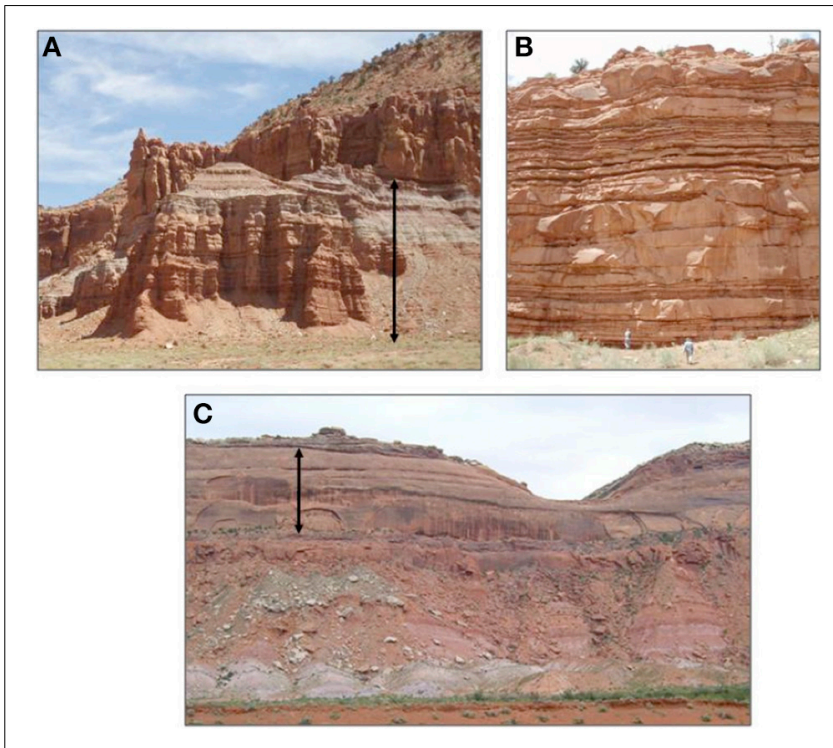

FIGURE 1 | (A) Moenave Formation at Potter Canyon, AZ, indicated by the arrow; (B) Moenave Formation at Tom's Canyon, Kanab, UT; (C) Wingate Sandstone at Comb Ridge, UT, indicated by arrow [photo credits: $(\mathbf{A}, \mathbf{B}) \mathrm{A}$. McCall; (C) S. Daman]. 
(Harshbarger et al., 1957; Wilson, 1967; Clemmensen et al., 1989; Olsen, 1989; Irby, 1996; Lucas and Heckert, 2001; Tanner et al., 2002; Molina-Garza et al., 2003; Tanner and Lucas, 2007). The age of the Moenave Formation is Late Triassic (Rhaetian) at its base and Early Jurassic at its top (Hettangian), as constrained by biostratigraphy (Morales, 1996; Lucas et al., 1997; Lucas and Heckert, 2001; Molina-Garza et al., 2003; Lucas and Tanner, 2007a). The laterally equivalent Wingate Sandstone (Figure 1C) is an eolian sandstone which is also dated through biostratigraphy as spanning the TJB (Lockley et al., 1992, 2004; Lucas et al., 1997; Molina-Garza et al., 2003; Lucas and Tanner, 2007a). Based on the biostratigraphy and magnetostratigraphy correlated with the Newark Basin, the Moenave and Wingate Formations were deposited over a period between 2 and 7 myr, (Molina-Garza et al., 2003; Lucas and Tanner, 2007a; Walker and Geissman, 2009). The geographic extent of these strata is restricted to the $\mathrm{CP}$, and they are exposed in southern Utah and northern Arizona (Tanner and Lucas, 2007). Donohoo-Hurley et al. (2010) successfully completed a detailed magnetostratigraphic correlation between the TJB in the Moenave Formation and the TJB in marine and non-marine successions in the United Kingdom, Turkey, the Southern Alps, Morocco, and the Newark Basin in eastern NA.

The Moenave and Wingate Formations were studied paleomagnetically by several workers to verify the presence of a cusp in the APW path for NA from the CP at $201 \mathrm{Ma}$ or to resolve the amount of rotation of the $\mathrm{CP}$ with respect to the stable craton. Paleopoles from the Mesozoic strata on the CP from previous workers (Steiner, 1986, 1988; Ekstrand and Butler, 1989; Kent and Witte, 1993; Molina-Garza et al., 1995, 1998, 2003; Steiner and Lucas, 2000) are all displaced west of the paleopoles determined from the rift basins of eastern NA. The most recent TJB paleopole from the CP is from Molina-Garza et al. (2003), who also conducted a detailed rock magnetic study of these strata, determining that their paleomagnetism is carried primarily by hematite. Molina-Garza et al.'s (2003) microscopic examination of their samples suggests that the hematite is mostly authigenic rather than of detrital origin, and therefore Molina-Garza et al. conclude that inclination shallowing during deposition was likely not present in the Moenave and Wingate Formations.

Molina-Garza et al.'s paleopole for $201 \mathrm{Ma}$ included samples from the Springdale Sandstone Member of Kayenta Formation overlying the Moenave Formation and the Rock Point Member of the Chinle Formation below the Wingate Sandstone, which were not sampled in this study because the cusp in the North American APWP has been constrained to lie within the Moenave and Wingate Formations (Ekstrand and Butler, 1989; Molina-Garza et al., 1998, 2003).

\section{METHODS}

The Moenave Formation was sampled at natural outcrops and road cuts across southern Utah and northern Arizona, from 35 sites at six localities; Washington Dome and Warner Valley near St. George, UT; Leeds/Historic Babylon, UT; Potter Canyon, AZ; Echo Cliffs; AZ; and the area directly surrounding Kanab, UT (Figure 2). The Wingate Sandstone was sampled in southeastern Utah at five sites in the road cut that bisects Comb Ridge

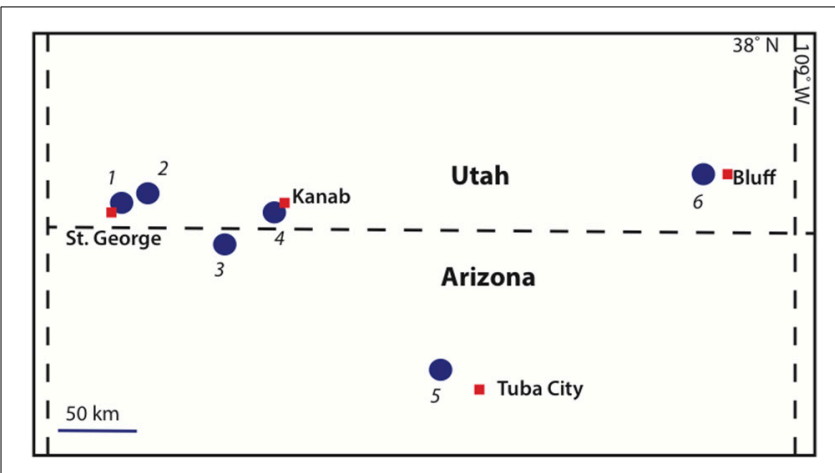

FIGURE 2 | Location map showing sampling locations. The east-west dashed line is the boundary between Utah and Arizona. Blue circles indicate sampling locations. 1. Washington Dome \& Warner Valley, near St. George, UT; 2. Leeds/Historic Babylon, UT; 3. Potter Canyon, AZ; 4. Kanab, UT; 5. Echo Cliffs, AZ; 6. Comb Ridge, near Bluff, UT.

near the city of Bluff (Figure 2). Samples were collected from different stratigraphic levels within the sites and within the formations, so that secular variation could be averaged. Six to nine samples were collected from each site using a portable gasolinepowered chain saw that had been modified to be a rock drill with a $25 \mathrm{~mm}$ diameter diamond-core bit. Each drill-core sample yielded one or more individual specimens, one for thermal demagnetization and additional samples for inclination shallowing studies. Samples were collected from fine sandstone to coarse siltstone horizons. Samples were trimmed to $25 \mathrm{~mm}$ lengths for thermal demagnetization and eventually trimmed to be $9 \mathrm{~mm}$ diameter by $8 \mathrm{~mm}$ length cores for high-field IRM anisotropy measurements (Bilardello and Kodama, 2009).

The samples were analyzed at Lehigh University's paleomagnetism laboratory. All measurements were made on a 2G Enterprises 755 superconducting magnetometer. Thermal demagnetization was used to isolate the characteristic remanent magnetization (ChRM) directions using an ASC Scientific Thermal Specimen Demagnetizer (Model TD-48 SC). Heating steps for demagnetization started at $125^{\circ} \mathrm{C}$ to determine if goethite was present in the samples and whether it needed to be demagnetized in the high-field anisotropy measurements. The progressive thermal demagnetization used 12-13 steps up to $685^{\circ} \mathrm{C}$. Principal component analysis (Kirschvink, 1980) was used to determine the ChRM. Characteristic magnetizations with a maximum angular deviation (MAD) of more than $12^{\circ}$ were excluded from the final site mean, and if all of the specimens for a site had MADs $>12^{\circ}$, that site was excluded from the formation mean. Site and formation means were calculated using Fisher statistics (Fisher, 1953).

The inclination shallowing correction is based on Jackson et al. (1991) and assumes that magnetic anisotropy of a sample increases linearly with inclination flattening as a sample is compacted. The flattening follows the equation:

$$
\tan I_{m}=f \tan I_{o}
$$

from King (1955) where $I_{m}$ is the measured inclination, $I_{o}$ is the initial, pre-flattening inclination, and $f$ is flattening factor $(0<\mathrm{f}$ 
$<1$ ). Jackson et al. (1991) have established a relationship between remanence anisotropy and the f factor for magnetite particles. Tan and Kodama (2002) have modified this relationship for hematite particles (see below).

A flattening factor was determined for each site using the site's mean direction and the site's mean high field anisotropy. The flattening factors were used to correct for inclination shallowing following the high field anisotropy method (Bilardello and Kodama, 2009; Kodama, 2012). Small subsamples (9 mm diameter by $8 \mathrm{~mm}$ long) were drilled from the standard paleomagnetic cores. High field isothermal remanent magnetizations (hf-IRMs) were applied to the small subsamples in an ASC Scientific Impulse Magnetizer (Model IM-10-30). The subsamples were given the IRM in a field of $5 \mathrm{~T}$ in 9 different orientations, heated to $125^{\circ} \mathrm{C}$ to remove goethite magnetizations, then remeasured after each hf-IRM and heating. To be sure that the $5 \mathrm{~T}$ IRM had totally saturated the magnetization, IRM acquisition measurements were made in 15 steps up to $5 \mathrm{~T}$ to determine if the specimens' magnetizations were saturated.

The anisotropy data were fitted by least squares to a second rank anisotropy tensor following the method of McCabe et al. (1985). The eigenvalues from the specimens from each of the sites were averaged; then the flattening factor $(f)$ could be calculated for that site, following the method of Tan and Kodama (2002):

$$
\left.f=\left[k_{\min }(2 a+1)-1\right] /\left[k_{\max }(2 a+1)-1\right)\right]
$$

where $k_{\min }$ and $k_{\max }$ are the site average minimum and maximum eigenvalues of the remanence anisotropy and $a$ is individual particle anisotropy of the magnetic grains carrying the remanence. The value of individual particle anisotropy, $a$, for hematite used in this study was 1.45 , as determined by Kodama (2009). The equation used to correct the measured inclination $\left(I_{m}\right)$ to the corrected inclination $\left(I_{c}\right)$ with the calculated flattening factor $(f)$ is:

$$
\tan I_{c}=\tan I_{m} / f
$$

from King (1955) where $I_{c}$ is the corrected inclination and $I_{m}$ is the measured inclination. The high-field anisotropy measurements were made for 3-6 specimens from each site, and the average flattening factor for each site was used to correct each site's mean direction. From the corrected site means, an inclinationcorrected VGP for each site was calculated. The site VGP's were then averaged using Fisher statistics to determine a CP paleopole for $201 \mathrm{Ma}$. The inclination shallowing corrected CP paleopole was rotated about a CP-local Euler pole from Hamilton (1988) $\left(34.6^{\circ} \mathrm{N}, 105.5^{\circ} \mathrm{W}\right)$ to determine how much rotation of the $\mathrm{CP}$ was necessary to bring the inclination-corrected TJB paleopole into agreement with the corrected eastern North American basins' paleopole, and to check if a vertical axis rotation of the $\mathrm{CP}$ will bring the corrected CP paleopole into agreement with the coeval eastern NA paleopole.

\section{RESULTS}

\section{DEMAGNETIZATION RESULTS}

The Moenave and Wingate Formation strata have remanent magnetizations that commonly show two or more unblocking temperature magnetization components (Figures 3A-C). Lower unblocking temperature components were typically removed after heating to 400 or $500^{\circ} \mathrm{C}$, but for some specimens, heating to $600^{\circ} \mathrm{C}$ was necessary to remove the lower unblocking temperature overprints. The characteristic remanence (ChRM) could only be isolated by unblocking temperatures between about

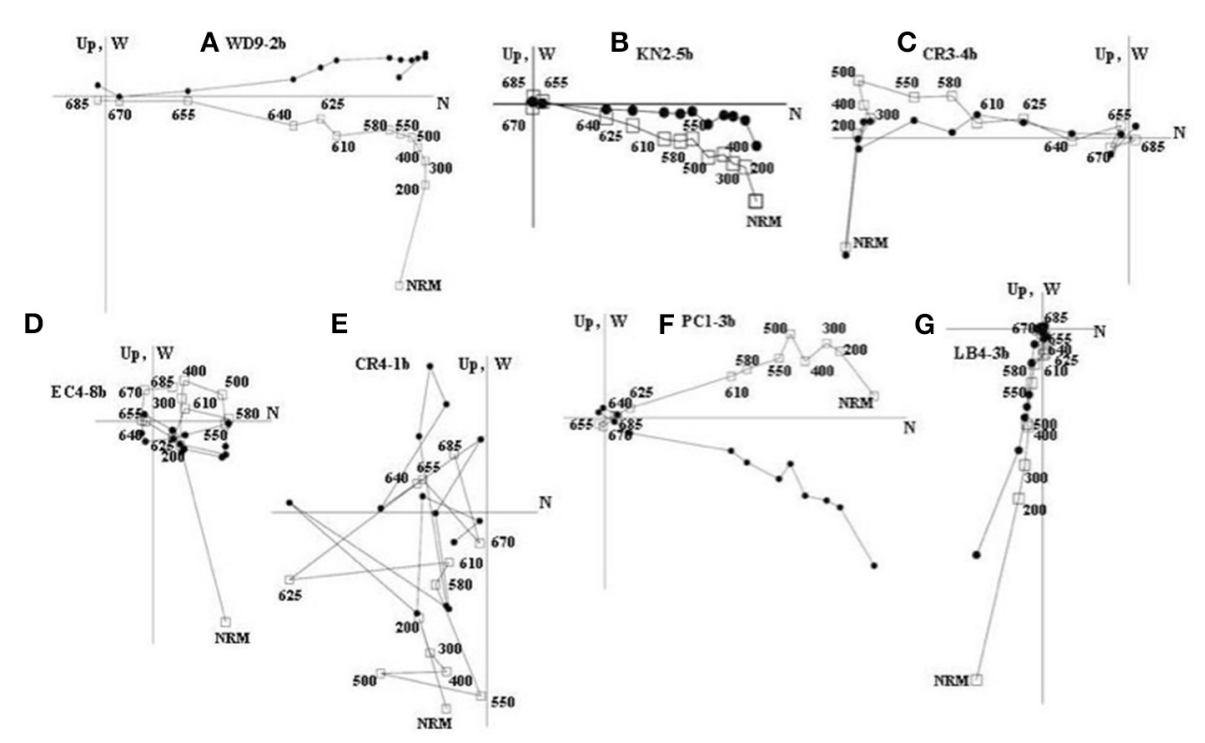

FIGURE 3 | Examples of demagnetization results; (A,B) are examples of northerly, shallow directions typical of the Moenave Formation; (C) is reversed polarity from the Wingate Formation; (D) (Moenave) and (E) (Wingate) did not yield clear directions from demagnetization; (F,G) are examples of sites possibly remagnetized or recording an excursion in the Moenave Formation. Solid circle trends are the declination and square open trends are inclinations. 
600 to $685^{\circ} \mathrm{C}$. When the ChRM could not be isolated and the MAD was greater than $12^{\circ}$ (Figures 3F,G), the specimen was rejected, unfortunately leading to a high rejection percentage in some sites, often over $50 \%$. Sites having less than three specimens meeting the MAD criteria had to be rejected because Fisher statistics could not be calculated. If the site mean had a $95 \%$ confidence radius $\left(\alpha_{95}\right)$ greater than $15^{\circ}$, it was also rejected. Some sites appear to be completely remagnetized or possibly record a magnetic field excursion, such as sites LB4 and PC1 (Table 1; Figures 3D,E), as they are outliers to the distribution of northerly, shallow directions; these were also omitted from the final uncorrected formation mean (Figures 4A,B). The mean direction for the Moenave and Wingate Formations, with stratigraphic tilt correction, but without inclination shallowing correction is $D=$ $358.8^{\circ}, I=12.8^{\circ}\left(N=20\right.$ sites, $k=31.8, \alpha_{95}=5.9^{\circ}$; Table 1; Figure 4), which, when compared to Molina-Garza et al.'s (2003) direction for the Moenave and Wingate Formations only, is statistically the same using the discrimination of means method (McFadden and Lowes, 1981). This study's mean direction was also compared to Donohoo-Hurley et al.'s (2010) more recent results from the Moenave Formation and it is statistically indistinguishable from their mean direction $\left(D=2.9^{\circ} ; I=14.6^{\circ}\right.$; $N=58 ; k=13.7 ; \alpha_{95}=5.2^{\circ}$ ).

\section{ANISOTROPY RESULTS}

IRM acquisition measurements (Figure 5) show that the magnetizations of the specimens were nearly saturated by $5 \mathrm{~T}$. The magnetizations of all three specimens started to saturate by about 3.5 T (Figure 5). Modeling of the IRM acquisition curves (Kruiver et al., 2001) indicates two coercivity components in the samples. Most of the magnetization (80-85\%) has a mean coercivity of $795 \mathrm{mT}$ while the remainder has a mean coercivity of $100 \mathrm{mT}$. Considered in light of the thermal demagnetization results would suggest the presence of hematite $(795 \mathrm{mT}$ coercivity component and $685^{\circ} \mathrm{C}$ unblocking temperatures) and perhaps some minor amounts of magnetite ( $100 \mathrm{mT}$ coercivity component and $400-500^{\circ} \mathrm{C}$ unblocking temperatures).

Anisotropy measurements showed a bedding parallel fabric present in the high-field IRM (Figure 6); when plotted, the minimum, intermediate, and maximum axes of high field-IRM magnetizations show a preferred orientation, with the maximum and intermediate axes oriented nearly parallel to bedding and the minimum axes nearly perpendicular to bedding. A flattening factor for each site was calculated (Table 1), with values for $f$ ranging from 0.58 to 0.84 . An average flattening factor for the Moenave $(f=0.69)$ was not applied to the mean of the site means because of the differences in lithology between sites; instead, each site mean was corrected by the site's average anisotropy. The mean $\mathrm{f}$ factor for the Moenave Formation compares reasonably well with the tabulation by Kodama (2012) which indicates $f=0.6$ for hematite-bearing rocks and $f=0.7$ for magnetite-bearing rocks. The inclination-corrected stratigraphic coordinate mean direction for the Moenave and Wingate at $\sim 201 \mathrm{Ma}$ is $D=358.7^{\circ}$, $I^{\prime}=17.9^{\circ}\left(N=20\right.$ sites, $k=25.9, \alpha_{95}=6.5^{\circ}$; Table 1$)$, a steepening of the inclination by $5.1^{\circ}$, and a calculated paleolatitude for the Moenave and Wingate Formations at the time of deposition is $\sim 9^{\circ}$ N. Bilardello et al.'s (2011) study of error propagation in an anisotropy-based inclination shallowing correction indicates that for reasonable errors in the estimation of the $\mathrm{f}$ factor $(<30 \%)$, the $\alpha_{95}$ cone of confidence is increased by less than a degree and the magnitude of the correction is affected by a similar amount. Therefore, error propagation was not conducted.

The elongation/inclination (E/I) technique (Tauxe and Kent, 2004) is an alternative way of correcting inclination shallowing; however, it needs a large number of samples $(\sim 100)$ for a wellconstrained correction. Since the mean direction for the Moenave and Wingate Formations reported here is statistically indistinguishable from Donohoo-Hurley et al.'s (2010) mean direction for the same formations, the datasets were combined to yield $N=78$ and allow an E/I inclination correction to compare to the anisotropy-based correction reported here. The E/I corrected inclination for the combined datasets was $17.2^{\circ}$ and compares very favorably with the anisotropy-based corrected inclination $\left(17.9^{\circ}\right)$. The $95 \%$ confidence interval around the E/I corrected inclination $\left(I=12^{\circ}\right.$ to $I=24^{\circ}$ or $\left.-4.9^{\circ} /+6.1^{\circ}\right)$ is comparable to the anisotropy-based $95 \%$ confidence limit of $6.5^{\circ}$.

\section{DISCUSSION}

The latitudes of the uncorrected and inclination shallowing corrected paleopoles calculated are not significantly different. The uncorrected, unrotated paleopole determined for the Moenave and Wingate Formations on the $\mathrm{CP}$ is $59.6^{\circ} \mathrm{N}, 69.6^{\circ} \mathrm{E}(\mathrm{N}=20$ sites, $\alpha_{95}=5.2^{\circ}$ ) (Figure 7). When corrected for the measured inclination shallowing for each site, the corrected, unrotated mean paleopole for the Moenave and Wingate Formations on the $\mathrm{CP}$ is $62.5^{\circ} \mathrm{N}, 69.9^{\circ} \mathrm{E}\left(N=20\right.$ sites, $\left.\alpha_{95}=5.5^{\circ}\right)$. The inclination corrected paleopole location shifted $2.9^{\circ}$ northwards, less than the $95 \%$ confidence limit for each paleopole. In this case, the inclination shallowing effects did not significantly change the paleomagnetic pole location from the uncorrected CP paleopole. In their study to generate a magnetostratigraphy for the Late Triassic and Early Jurassic on the CP, Molina-Garza et al. (2003) determined that the weak magnetic remanence in the Moenave and Wingate Formations is carried by a hematite grain coating, which was sometimes irregular, rather than detrital hematite; therefore, they argued that the paleomagnetic inclinations were not shallowed during deposition. The shallowed inclinations that were measured in this study were probably flattened during burial compaction, suggesting an early chemical remanent magnetization (CRM) for the remanence, assuming Molina-Garza et al.'s (2003) interpretation of a CRM as the primary remanence carrier.

The average flattening factor for the Moenave is 0.69 , which is one standard deviation away from the average flattening factor calculated for redbeds $(0.58 \pm 0.11)$ by Bilardello and Kodama (2010) and consistent with Kodama's (2012) average of tabulated inclination shallowing $(f=0.6)$ studies for hematite-bearing rocks. These tabulations are based on values ranging from a low value of 0.4 measured in the Newark Supergroup redbeds of the Newark Basin (Kent and Tauxe, 2005) to a high value of 0.83 measured in Carboniferous redbeds from New Brunswick and Nova Scotia (Bilardello and Kodama, 2009, 2010; Kodama, 2012). This study's results fall within this range (Table 1). If a CRM has a flattening factor of $\sim 0.7$, the magnitude of shallowing would be greater for steeper inclinations than observed in 
Table 1 | Paleomagnetic data and statistical parameters.

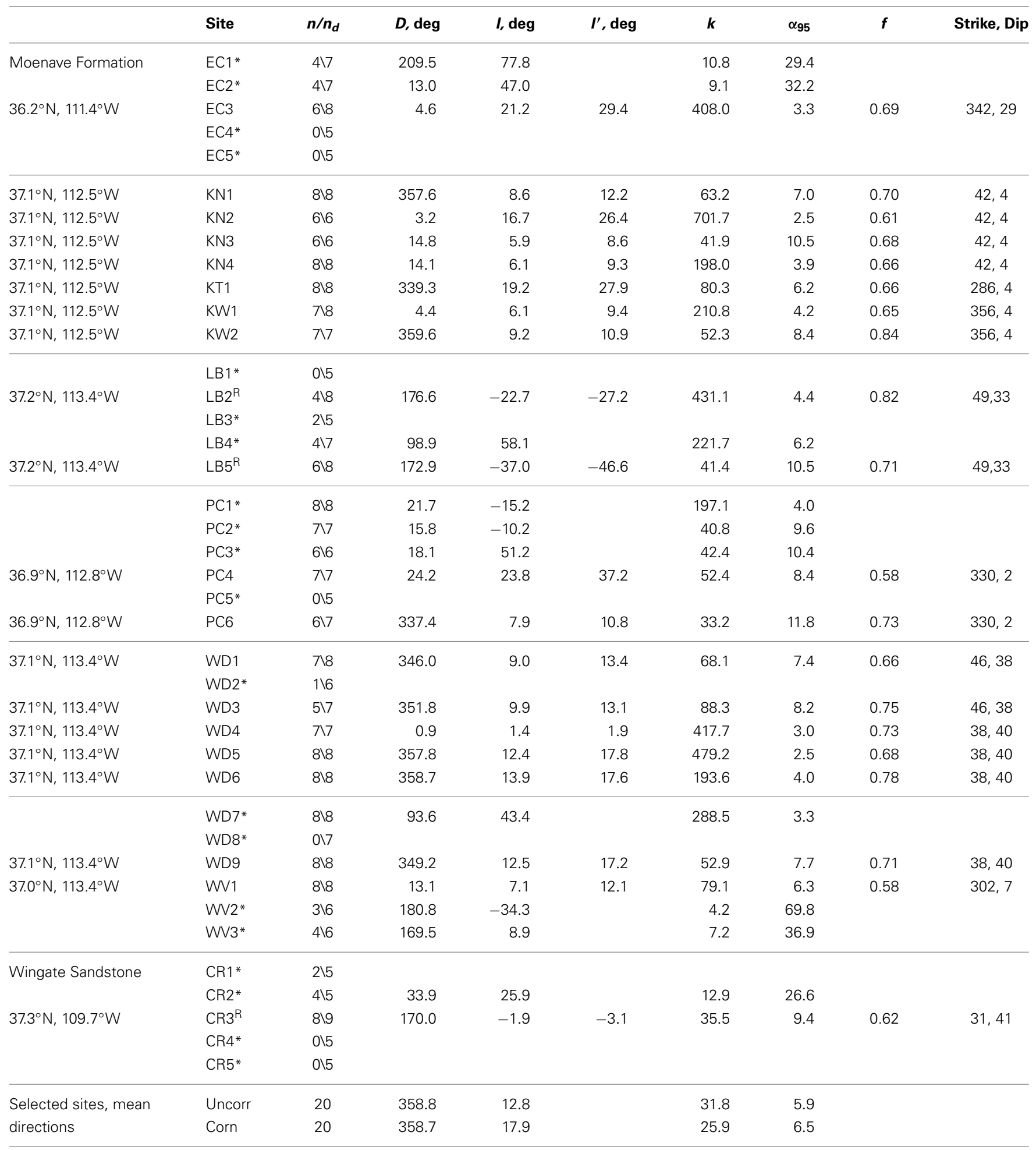

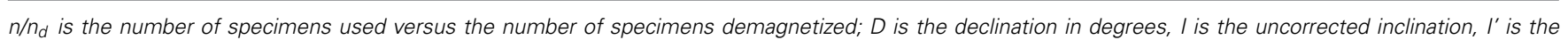
corrected inclination, $k$ is Fisher's precision parameter, $\alpha 95$ is the radius of the confidence interval around the mean.

${ }^{*}$ Indicates sites excluded from the final calculations, as explained in the text. ${ }^{R}$ Indicates sites which are reversed.

$E C,=$ Echo Cliffs, AZ; KN = Northern Kanab, UT; KT = Tom's Canyon, Kanab, UT; KW = Western Kanab, UT; LB = Leeds/Historic Babylon, UT; PC $=$ Potter Canyon, $A Z ; W D=$ Washington Dome, St. George, UT; WV = Warner Valley, St. George, UT; CR = Comb Ridge, near Bluff, UT.

Strike, dip follows the convention that strike is to the left when looking down dip. 
the Moenave Formation. The Moenave and Wingate Formation sites that were sampled typically have lithologies of fine sandstones and coarse siltstones, but medium sand was present in a few sites. These coarser specimens would have experienced less compaction and therefore less shallowing of the inclinations. The small amount of inclination shallowing is consistent with Molina-Garza et al.'s (2003) observation of pigmentary chemically precipitated hematite rather than detrital hematite being the dominant magnetic mineral carrying the remanence.

With the inclination shallowing corrected, the amount of rotation of the CP necessary to bring the coeval paleopoles into agreement can be calculated using Demarest's (1983) approach as reported in Butler (1992). When the inclination corrected CP mean paleopole for the TJB is rotated about an Euler pole local to the $\mathrm{CP},\left(34.6^{\circ} \mathrm{N}, 105.5^{\circ} \mathrm{W}\right.$; Hamilton, 1988$)$, the amount of rotation needed to align the longitude of the $\mathrm{CP}$ paleopole with the coeval paleopole from the northeastern US is $9.7^{\circ}$, yielding a rotated, corrected paleopole for the $\mathrm{CP}$ at $61.7^{\circ} \mathrm{N}, 90.5^{\circ} \mathrm{E}(\mathrm{N}=$ $20, \alpha_{95}=5.5^{\circ}$ ), with a calculated error on the rotation of $\pm 5^{\circ}$. The corrected, rotated CP paleopole is statistically indistinguishable from the eastern NA basin corrected paleopole (Kent and Olsen, 2008) using the discrimination of means (McFadden and Lowes, 1981). If the uncorrected paleopole is rotated $10.1^{\circ}$ about the CP Euler pole the uncorrected, rotated CP paleopole is statistically different from the eastern NA basins' paleopole. This result

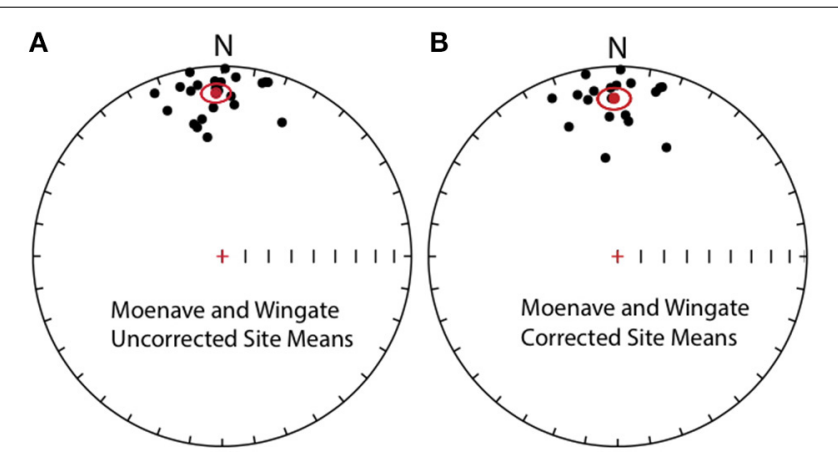

FIGURE 4 | (A, Left) Equal area net showing Moenave and Wingate Formations uncorrected site means and mean of the site means with $95 \%$ confidence cone in red. (B, Right) Moenave and Wingate Formations corrected site means and mean of site means (red). suggests that the $\mathrm{CP}$ rotated on the order of $10^{\circ}$ clockwise since the deposition of the Moenave Formation and Wingate Sandstone and that the westward displacement in the APW path for NA from the CP is likely an artifact of this rotation as suggested previously by many workers (e.g., Kent and Witte, 1993; Kent and Olsen, 2008).

With the amount of rotation of the $\mathrm{CP}$ calculated, the amount of translation along an arc around the Euler pole can be calculated. This amount varies with distance from the Euler pole, but was calculated for the approximate location of the eastern edge of the piercing point on the CP from Cather (1999). The $\sim 10^{\circ}$ of rotation at a point to close to the CP Euler pole in eastern New Mexico yields only $\sim 20 \mathrm{~km}$ of northeastern translation. This is less than the displacement Cather (1999) calculated for the eastern edge of the CP in New Mexico using stratigraphic pinchouts as piercing points, with amounts range from 33 to $110 \mathrm{~km}$. The

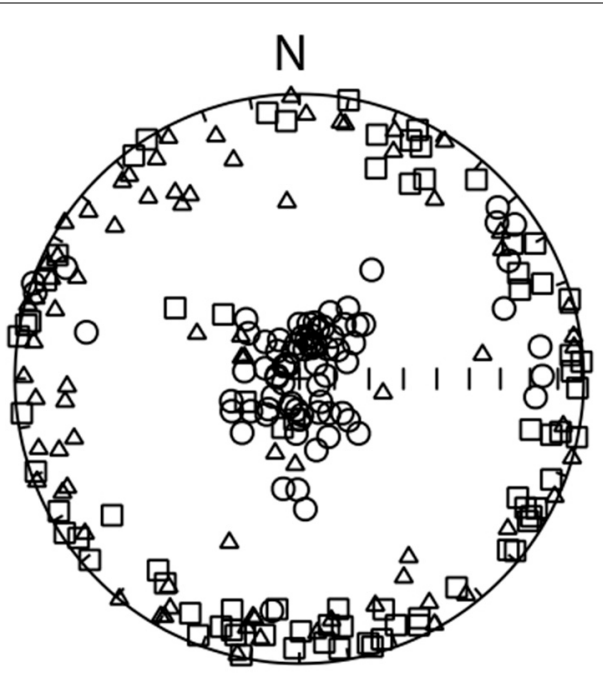

FIGURE 6 | Equal area net showing Moenave Formation high field anisotropy results in stratigraphic coordinates. Open circles are minimum axes, squares are maximum axes, and triangles are intermediate axes, all points lower hemisphere. Minimum axes are perpendicular to bedding, with maximum (and intermediate) axes lying in the bedding plane indicating a bedding parallel fabric typical of deposition and compaction in sedimentary rocks.
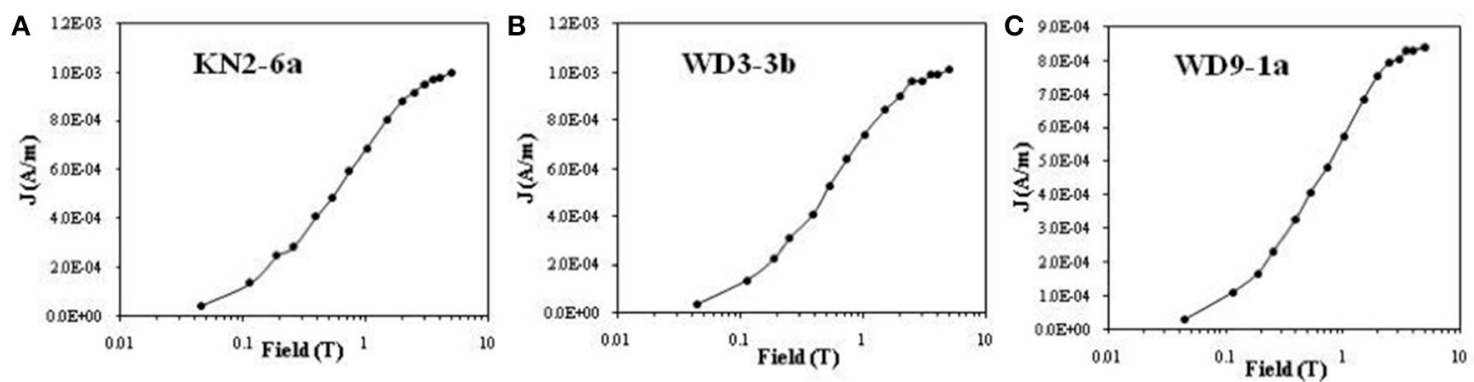

FIGURE 5 | IRM acquisition of Moenave Formation samples. All three samples (A, Northern Kanab; B,C, Washington Dome) have nearly reached saturation by $5 \mathrm{~T}$. 


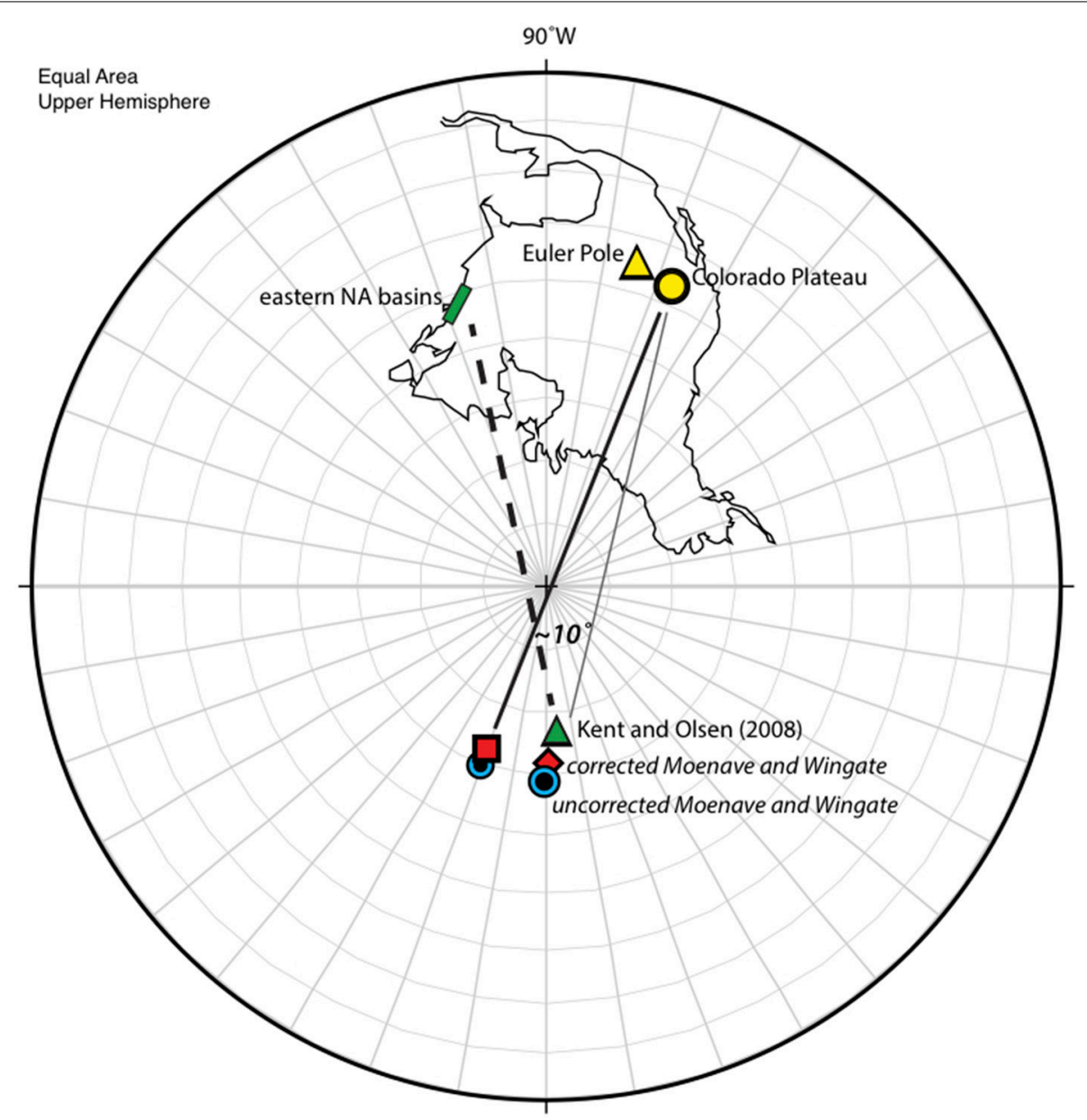

FIGURE 7 | Corrected (red) and uncorrected (blue) paleopoles from the Moenave and Wingate Formations shown in their in situ position (solid black line connects them to the Colorado Plateau locality) and with CP rotation removed (light gray line connects to the Colorado Plateau locality). The Kent and Olsen (2008) paleopole (green triangle) is the reference pole from the eastern NA basins (dashed line connects to its locality). A rotation of $\sim 10^{\circ}$ will bring the CP Moenave and Wingate paleopole into agreement with the eastern North American basin paleopole. discrepancy could suggest that the Euler pole for CP rotation is further from the CP as suggested by Cather (1999) or that the geological observations overestimate the amount of displacement along the fault systems.

\section{CONCLUSIONS}

Inclination shallowing corrections for the Moenave Formation and the Wingate Sandstone on the CP have significant implications for the amount of CP rotation and translation, as well as the paleomagnetic remanence in red beds. Even though the remanence in these red beds is a CRM, both the anisotropy-based inclination correction reported here and an E/I correction confirm inclination shallowing with $f=0.7$. The shallowing was probably caused by burial compaction, if the CRM was acquired shortly after deposition and before significant amounts of burial. When corrected for inclination shallowing, the paleopole for the $\mathrm{CP}$ at the Triassic/Jurassic boundary, $\sim 201 \mathrm{Ma}$, shifts $2.9^{\circ}$ northwards in latitude. The inclination-corrected paleopole, when rotated about a CP local Euler pole $9.7 \pm 5^{\circ}$ to account for clockwise rotation of the plateau, matches the coeval corrected eastern NA paleopole, at the $95 \%$ confidence level. The amount of translation of the CP calculated from the rotation is smaller than geological estimates of fault displacement along the eastern edge of the CP.

\section{ACKNOWLEDGMENTS}

Thanks goes to Stuart Daman for help in the field; Dario Bilardello for help in the laboratory; Linda Donohoo-Hurley and John Geissman for locality details; Brad Nesemeier \& the Navajo Nation for their permission to sample on their land; and Russell Schreiner \& the BLM for sampling permission. Lehigh University Department of Earth and Environmental Sciences provided funds to Andrea M. McCall to support the field sampling.

\section{REFERENCES}

Bilardello, D., Jezek, J., and Kodama, K. P. (2011). Propagating and incorporating the error in anisotropy-based inclination corrections. Geophys. J. Int. 187, 75-84. doi: 10.1111/j.1365-246X.2011.05138.x 
Bilardello, D., and Kodama, K. P. (2009). Measuring remanence anisotropy of hematite in red beds: anisotropy of high-field isothermal remanence magnetization (hf-AIR). Geophys. J. Int. 178, 1260-1272. doi: 10.1111/j.1365246X.2009.04231.x

Bilardello, D., and Kodama, K. P. (2010). Palaeomagnetism and magnetic anisotropy of Carboniferous red beds from the Maritime Provinces of Canada: evidence for shallow palaeomagnetic inclinations and implications for North American apparent polar wander. Geophys. J. Int. 180, 1013-1029. doi: 10.1111/j.1365-246X.2009.04457.x

Bird, P. (1998). Kinematic history of the Laramide Orogeny in latitudes $35^{\circ}-49^{\circ} \mathrm{N}$, western United States. Tectonics 17, 780-801. doi: 10.1029/98TC02698

Bryan, P., and Gordon, R. G. (1986). Rotation of the Colorado Plateau: an analysis of paleomagnetic data. Tectonics 5, 661-667. doi: 10.1029/TC005i004p00661

Bryan, P., and Gordon, R. G. (1990). Rotation of the Colorado Plateau: an updated Analysis of paleomagnetic poles. Geophys. Res. Lett. 17, 1501-1504. doi: 10.1029/GL017i010p01501

Butler, R. F. (1992). Paleomagnetism, Magnetic Domains to Geologic Terranes. Boston, MA: Blackwell Scientific Publications.

Cather, S. M. (1999). Implications of Jurassic, Cretaceous, and Proterozoic piercing lines for Laramide oblique-slip faulting in New Mexico and rotation of the Colorado Plateau. Geol. Soc. Am. Bull. 111, 849-868.

Clemmensen, L. B., Olsen, H., and Blakey, R. C. (1989). Erg-margin deposits in the Lower Jurassic Moenave Formation and Wingate Sandstone, southern Utah. Geol. Soc. Am. Bull. 101, 759-773.

Demarest, H. H. (1983). Error anlaysis of the determination of tectonic rotation from paleomagnetic data. J. Geophys. Res. 88, 4321-4328. doi: 10.1029/JB088iB05p04321

Donohoo-Hurley, L. L., Geissman, J. W., and Lucas, S. G. (2010). Magnetostratigraphy of the uppermost Triassic and lowermost Jurassic Moenave Formation, western United States: correction with strata in the United Kingdom, Morocco, Turkey, Italy, and eastern United States. Geol. Soc. Am. Bull. 122, 2005-2019. doi: 10.1130/B30136.1

Ekstrand, E. J., and Butler, R. F. (1989). Paleomagnetism of the Moenave Formation: implications for the Mesozoic North American apparent polar wander path. Geology 17, 245-248.

Fisher, R. A. (1953). Dispersion on a sphere. Proc. R. Soc. Lond. A 217, 295-305. doi: 10.1098/rspa.1953.0064

Gordon, R. G., Cox, A., and O'Hare, S. (1984). Paleomagnetic Euler poles and the apparent polar wander and absolute motion of North America since the Carboniferous. Tectonics 3, 499-537.

Hames, W. E., Renne, P. R., and Ruppel, C. (2000). New evidence for geologically instantaneous emplacement of earliest Jurassic Central Atlantic magmatic province basalts on the North American margin. Geology 28, 859-862.

Hamilton, W. (1988). "Tectonic setting and variation with depth of some Cretaceous and Cenozoic structural and magmatic systems of the Western United States," in Rubey, Vol. VII, ed W. G. Ernst (Englewood Cliffs, NJ: Prentice-Hall), 1-40

Hamilton, W. B. (1981). Plate-tectonic mechanism of Laramide deformation. Univ. Wyoming Contribut. Geol. 19, 87-92.

Harshbarger, J. W., Repenning, C. A., and Irwin, J. H. (1957). Stratigraphy of the uppermost Triassic and Jurassic rocks of the Navajo Country. U.S. Geol. Surv. Prof. Pap. 291, 1-74.

Irby, G. V. (1996). "Synopsis of the Moenave Formation," in Guidebook for the Geological Excursion of the Continental Jurassic Symposium, ed M. Morales (Flagstaff, AZ: Museum of Northern Arizona), 3-14.

Jackson, M. J., Banerjee, S. K., Marvin, J. A., Lu, R., and Gruber, W. (1991). Detrital remanence, inclination errors, and anhysteretic remanence anisotropy: quantitative model and experimental results. Geophys. J. Int. 104, 95-103. doi: 10.1111/j.1365-246X.1991.tb02496.x

Kent, D. V., and Irving, E. (2010). Influence of inclination error in sedimentary rocks on the Triassic and Jurassic apparent pole wander path for North America and implications for Cordilleran tectonics. J. Geophys. Res. 115, 1-25. doi: 10.1029/2009JB007205

Kent, D. V., and Olsen, P. E. (1997). Paleomagnetism of Upper Triassic continental sedimentary rocks from the Dan River-Danville rift basin (eastern North America). Geol. Soc. Am. Bull. 109, 366-377.

Kent, D. V., and Olsen, P. E. (1999). Astronomically tuned geomagnetic polarity time scale for the Late Triassic. J. Geophys. Res. 104, 12831-12841. doi: 10.1029/1999JB900076
Kent, D. V., and Olsen, P. E. (2008). Early Jurassic magnetostratigraphy and paleolatitudes from the Hartford continental rift basin (Eastern North America): testing for polarity bias and abrupt polar wander in association with the central Atlantic magmatic province. J. Geophys. Res. 113, B06105. doi: 10.1029/2007JB005407

Kent, D. V., Olsen, P. E., and Witte, W. K. (1995). Late Triassic-earliest Jurassic geomagnetic polarity sequence and paleolatitudes from drill cores in the Newark rift basin, eastern North America. J. Geophys. Res. 100, 14965-14998. doi: 10.1029/95JB01054

Kent, D. V., and Tauxe, L. (2005). Corrected late triassic latitudes for continents adjacent to the North Atlantic. Science 307, 240-244. doi: 10.1126/science. 1105826

Kent, D. V., and Witte, W. K. (1993). Slow apparent polar wander for North America in the Late Triassic and large Colorado Plateau rotation. Tectonics 12, 291-300. doi: 10.1029/92TC01966

King, R. F. (1955). The remanent magnetism of artificially deposited sediments Mon. Notic. R. Astr. Soc. Geophys. Suppl. 7, 115-134. doi: 10.1111/j.1365246X.1955.tb06558.x

Kirschvink, J. L. (1980). The least-square line and plane and the analysis of palaeomagnetic data. Geophys. J. R. Astr. Soc. 62, 699-718. doi: 10.1111/j.1365246X.1980.tb02601.x

Kodama, K. P. (1997). A successful rock magnetic technique for correcting paleomagnetic inclination shallowing: case study of the Nacimiento Formation, New Mexico. J. Geophys. Res. 102, 5193-5205. doi: 10.1029/96JB03833

Kodama, K. P. (2009). Simplification of the anisotropy-based inclination correction technique for magnetite- and haematite-bearing rocks: a case study for the Carboniferous Glenshaw and Mauch Chunk Formations, North America. Geophys. J. Int. 176, 467-477. doi: 10.1111/j.1365-246X.2008.04013.x

Kodama, K. P. (2012). Paleomagnetism of Sedimentary Rocks, Process and Interpretation. Oxford: Wiley-Blackwell.

Kodama, K. P., and Davi, J. M. (1995). A compaction correction for the paleomagnetism of the Cretaceous Pigeon Point Formation of California. Tectonics 14, 1153-1164. doi: 10.1029/95TC01648

Kruiver, P., Dekkers, M., and Heslop, D. (2001). Quantification of magnetic coercivity components by the analysis of acquisition curves of isothermal remanent magnetisation. Earth Planet. Sci. Lett. 189, 269-276. doi: 10.1016/S0012$821 \mathrm{X}(01) 00367-3$

Lockley, M. G., Conrad, K., Paquette, M., and Farlow, J. O. (1992). Distribution and significance of Mesozoic vertebrate trace fossils in Dinosaur National Monument. Univ. Wyoming Natl. Park Serv. Rep. 16, 64-85.

Lockley, M. G., Lucas, S. G., Hunt, A. P., and Gaston, R. (2004). Ichnofaunas from the Triassic-Jurassic boundary sequences of the Gateway area, Western Colorado: implications for Faunal Composition and Correlations with other areas. Ichnos 11, 89-102. doi: 10.1080/10420940490442331

Lucas, S. G., and Heckert, A. B. (2001). Theropod dinosaurs and the Early Jurassic age of the Moenave Formation, Arizona-Utah, USA. Neues Jahrbuch fur Geologie und Palaontologie. Monatshefte 2001, 435-448.

Lucas, S. G., Heckert, A. B., Estep, J. W., and Anderson, O. J. (1997). Stratigraphy of the upper triassic chinle group, four corners region. N.M. Geol. Soc. Guidebook $48,81-107$.

Lucas, S. G., and Tanner, L. H. (2007a). Tetrapod biostratigraphy and biochronology of the Triassic-Jurassic transition on the southern Colorado Plateau, USA. Palaeogeogr. Palaeoclimatol. Palaeoecol. 244, 242-256. doi: 10.1016/j.palaeo.2006.06.030

Lucas, S. G., and Tanner, L. H. (2007b). The nonmarine Triassic-Jurassic boundary in the Newark Supergroup of eastern North America. Earth Sci. Rev. 84, 1-20. doi: 10.1016/j.earscirev.2007.05.002

McCabe, C., Jackson, M., and Elwood, B. B. (1985). Magnetic anisotropy in the Trenton limestone: results of a new technique, anisotropy of anhysteretic susceptibility. Geophys. Res. Lett. 12, 333-336. doi: 10.1029/GL012i006p00333

McFadden, P. L., and Lowes, F. J. (1981). The discrimination of mean directions drawn from Fisher distributions. Geophys. J. R. Astron. Soc. 67, 19-33. doi: 10.1111/j.1365-246X.1981.tb02729.x

Molina-Garza, R. S., Acton, G. D., and Geissman, J. W. (1998). Carboniferous through Jurassic paleomagnetic data and their bearing on rotation of the Colorado Plateau. J. Geophys. Res. 103, 24179-24188. doi: 10.1029/98JB 02053

Molina-Garza, R. S., Geissman, J. W., and Lucas, S. G. (2003). Paleomagnetism and magnetostratigraphy of the lower Glen Canyon and upper Chinle Groups, 
Jurassic-Triassic of northern Arizona and northeast Utah. J. Geophys. Res. 108, 2181. doi: 10.1029/2002JB001909

Molina-Garza, R. S., Geissman, J. W., and Van der Voo, R. (1995). Paleomagnetism of the Dockum Group (Upper Triassic), northwest Texas: further evidence for the J1 cusp in the North American apparent polar wander path and implications for rate of Triassic apparent polar wander and Colorado Plateau rotation. Tectonics 14, 979-993. doi: 10.1029/95TC01456

Morales, M. (1996). "Brief report on theropod trackways in the Wingate Sandstone of Ward Terrace, Arizona," in The Continental Jurassic, No. 60, ed M. Morales (Flagstaff, AZ: Museum of Northern Arizona Bulletin), 169-171.

Olsen, H. (1989). Sandstone-body structures and ephemeral stream processes in the Dinosaur Canyon Member, Moenave Formation (Lower Jurassic), Utah, U.S.A. Sediment. Geol. 61, 207-221. doi: 10.1016/0037-0738(89) 90058-4

Olsen, P. E., and Kent, D. V. (1996). Milankovitch climate forcing in the tropics of Pangea during the Late Triassic. Palaeogeogr. Palaeoclimatol. Palaeoecol. 122, 1-26. doi: 10.1016/0031-0182(95)00171-9

Olsen, P. E., Koeberl, C., Huber, H., Montanari, A., Fowell, S. J., Et Touhami, M., et al. (2002). "Continental Triassic-Jurassic boundary in central Pangea: recent progress and discussion of an Ir anomaly," in Catastrophic Events and Mass Extinctions: Impacts and Beyond, Spec. Pap. Geol. Soc. Am., Vol. 356, eds C. Koeberl and K. G. Macleod (Boulder, CO: Geological Society of America), 505-522.

Olsen, P. E., Schlische, R. W., and Fedosh, M. S. (1996). "580 ky duration of the Early Jurassic flood basalt event in eastern North America estimated using Milankovitch cyclostratigraphy," in The Continental Jurassic, ed M. Morales (Flagstaff, AZ: Mus. of North. Ariz), 11-22.

Steiner, M. B. (1986). Rotation of the Colorado Plateau. Tectonics 5, 649-660. doi: 10.1029/TC005i004p00649

Steiner, M. B. (1988). Paleomagnetism of the Late Pennsylvanian and Permian: a test of the rotation of the Colorado Plateau. J. Geophys. Res. 93, 2201-2215. doi: 10.1029/JB093іB03p02201

Steiner, M. B., and Lucas, S. G. (2000). Paleomagnetism of the Late Triassic Petrified Forest Formation, Chinle Group, western United States: further evidence of "large" rotation of the Colorado Plateau. J. Geophys. Res. 105, 25791-25808. doi: 10.1029/2000JB900093

Tan, X., and Kodama, K. P. (1998). Compaction-corrected inclinations from southern California Cretaceous marine sedimentary rocks indicate no paleolatitudinal offset for the Peninsular Ranges terrane. J. Geophys. Res. 97, 27169-27192. doi: $10.1029 / 98 J B 02343$

Tan, X., and Kodama, K. P. (2002). Magnetic anisotropy and paleomagnetic inclination shallowing in red beds: evidence from the Mississippian Mauch Chunk Formation, Pennsylvania. J. Geophys. Res. 107, 2311. doi: 10.1029/2001JB001636
Tanner, L. H., and Lucas, S. G. (2007). The Moenave Formation: sedimentologic and stratigraphic context of the Triassic-Jurassic boundary in the Four Corners area, southwestern U.S.A. Palaeogeogr. Palaeoclimatol. Palaeoecol. 244, 111-125. doi: 10.1016/j.palaeo.2005.06.039

Tanner, L. H., Lucas, S. G., Reser, P. K., and Chapman, M. G. (2002). Revision of Stratigraphy across the Triassic-Jurassic boundary, Four Corners region, southwestern USA. Geol. Soc. Am. Abstr. Progr. 34, 138.

Tauxe, L., and Kent, D. V. (2004). "A simplified statistical model for the geomagnetic field and the detection of shallow bias in paleomagnetic inclinations: was the ancient magnetic field dipolar?," in Timescales of the Paleomagnetic Field, 145, eds J. E. T. Channell, D. V. Kent, W. Lowrie, and J. Meert (Washington, DC: American Geophysical Union), 101-116.

Tauxe, L., Kodama, K. P., and Kent, D. V. (2008). Testing corrections for paleomagnetic inclination error in sedimentary rocks: a comparative approach. Phys. Earth Planetary Inter. 169, 153-165. doi: 10.1016/j.pepi.2008.05.006

Vaughn, J., Kodama, K. P., and Smith, D. (2005). Correction of inclination shallowing and its tectonic implications: the Cretaceous Perforada Formation, Baja California. Earth Planet. Sci. Lett. 232, 72-82. doi: 10.1016/j.epsl.2004.11.026

Walker, J. D., and Geissman, J. W. (2009). 2009 GSA geologic time scale. GSA Today $19,4-5$.

Wawrzyniec, T. F., Geissman, J. W., Melker, M. D., and Hubbard, M. (2002). Dextral shear along the eastern margin of the Colorado Plateau - A kinematic link between the Laramide orogeny and Rio Grande rifting (ca. $80 \mathrm{Ma}$ to $13 \mathrm{Ma}$ ). J. Geol. 110, 305-324. doi: 10.1086/339534

Wilson, R. F. (1967). Whitmore Point, a new member of the Moenave Formation in Utah and Arizona. Plateau 40, 29-40.

Conflict of Interest Statement: The authors declare that the research was conducted in the absence of any commercial or financial relationships that could be construed as a potential conflict of interest.

Received: 12 March 2014; accepted: 07 July 2014; published online: 28 July 2014.

Citation: McCall AM and Kodama KP (2014) Anisotropy-based inclination correction for the Moenave Formation and Wingate Sandstone: implications for Colorado Plateau rotation. Front. Earth Sci. 2:15. doi: 10.3389/feart.2014.00015

This article was submitted to Geomagnetism and Paleomagnetism, a section of the journal Frontiers in Earth Science.

Copyright (c) 2014 McCall and Kodama. This is an open-access article distributed under the terms of the Creative Commons Attribution License (CC BY). The use, distribution or reproduction in other forums is permitted, provided the original author(s) or licensor are credited and that the original publication in this journal is cited, in accordance with accepted academic practice. No use, distribution or reproduction is permitted which does not comply with these terms. 